\title{
Bingung Memilih Obat Batuk? Kenalilah Jenis Batuk Anda!
}

\author{
Lily Cyntia Fauzi \\ Program Studi Profesi Apoteker, Fakultas Farmasi, Universitas Padjadjaran, Sumedang 45363 \\ email: lilycyntia123@gmail.com
}

\section{Abstrak :}

Salah satu penyakit yang umum terjadi adalah batuk. Batuk sendiri merupakan salah satu mekanisme pertahanan tubuh dari saluran pernapasan dan menjadi refleks yang terangsang karena adanya iritasi paru atau saluran pernapasan. Sebelum memilih obat batuk yang sesuai dengan Anda, perlu diketahui ada beberapa penyebab batuk yang tentunya juga membutuhkan agen terapi yang berbeda pula. Batuk yang terjadi dalam jangka waktu yang lama ini disebut dengan batuk kronis. Secara umum, ada dua jenis batuk, yaitu batuk akut dan batuk kronis. Batuk akut biasanya merupakan gejala adanya infeksi pada saluran pernapasan dan biasanya dapat sembuh dalam waktu tiga minggu. Adapula batuk kronis yang dapat berlangsung selama lebih dari 8 minggu. Batuk kronis dapat menyebabkan kelelahan, kesulitan tidur, dan apabila batuk makin parah dapat menyebabkan rusuk retak, penumotoraks dan emfisema. Alangkah baiknya jika pasien menjadi lebih bijak dan cerdas dalam memilih obat yang tepat dan sesuai dengan keluhan yang dirasakan. Konsultasikanlah kepada apoteker dalam untuk memastika pilihan obatnya.

Keyword : Obat, batuk, kronis, infeksi

\section{Outline}

- Pendahuluan

- Mengenal jenis obat batuk

- Kesimpulan

\section{Pendahuluan}

Pada zaman globalisasi ini, di Indonesia tersedia berbagai jenis makanan. Dimulai dari ayam goreng siap saji, bubble tea, kue kekinian dan kemudian merambat menjadi berbagai jenis makanan global lainnya. Kandungan gula dan garam serta lemak yang tinggi menjadikan makanan tersebut kurang menyehatkan.

Terutama sekarang ini, tersedia aplikasi transportasi online makanan dan minuman yang praktis sehingga konsumen cenderung menjadi lebih mudah dalam mengakses makanan atau minuman yang kurang sehat tersebut. Ditambah lagi dengan pemanasan global, dimana cuaca di Indonesia menjadi tidak menentu, membuat imun-imun masyarakat cenderung menurun dan menjadi mudah terserang penyakit. 
Salah satu penyakit yang umum terjadi adalah batuk. Batuk sendiri merupakan salah satu mekanisme pertahanan tubuh dari saluran pernapasan dan menjadi refleks yang terangsang karena adanya iritasi paru atau saluran pernapasan (Singh and Singh, 2013; Direktorat Bina Farmasi Komunitas dan Klinik, 2006).

Batuk juga menjadi tanda atau gejala dari gangguan pernapasan ataupun nonpernapasan. Untuk beberapa orang batuk ini sangat menganggu aktivitasnya sehingga masyarakat tersebut akan melakukan swamedikasi dan mencari obat batuk untuk menyembuhkan keluhan tersebut (Simpson and Amin, 2006). Namun, obat batuk apakah yang cocok untuk mengobati gejala tersebut? Walaupun terdengar hal yang sepele, masih banyak pasien yang bingung dalam memilih obat. Adapula pasien yang masih kurang tepat dalam memilih obat batuk yang tepat dan sesuai. Tidak jarang pasien dengan mudahnya memilih antibiotic dimana hal tersebut kurang tepat.

\section{Mengenal jenis obat batuk}

Sebelum memilih obat batuk yang sesuai dengan Anda, perlu diketahui ada beberapa penyebab batuk yang tentunya juga membutuhkan agen terapi yang berbeda pula. Batuk yang terjadi dalam jangka waktu yang lama dapat disebabkan oleh beberapa hal, seperti (lyer and Joshi, 2013):

- Infeksi virus

- Gastroesophageal reflux disease (GERD)

- Batuk yang dipicu asma

- Bronchitis eosinophil

- Penggunaan obat antihipertensi, yaitu ACEi, seperti captopril, lisinopril, dan lain-lain.

Batuk yang terjadi dalam jangka waktu yang lama ini disebut dengan batuk kronis. Secara umum, ada dua jenis batuk, yaitu batuk akut dan batuk kronis. Batuk akut biasanya merupakan gejala adanya infeksi pada saluran pernapasan dan biasanya dapat sembuh dalam waktu tiga minggu. Adapula batuk kronis yang dapat berlangsung selama lebih dari 8 minggu. Batuk kronis dapat menyebabkan kelelahan, kesulitan tidur, dan apabila batuk makin parah dapat menyebabkan rusuk retak, penumotoraks dan emfisema (lyer and Joshi, 2013).

Beberapa jenis kandungan obat batuk yang beredar bebas di Indonesia adalah:

\section{Batuk Berdahak}

Bromhexine $\mathrm{HCl}$

Obat ini merupakan mukolitik atau pengencer dahak. Adapula metabolit dari bromhexine adalah ambroxol (Garbis, 2007).

$\mathrm{N}$-asetilsistein

Obat ini merupakan mukolitik ataup pengencer dahak (Garbis, 2007). 
Gliseril guaiacolate atau guaiafenesin

GG merupakan salah satu obat batuk yang tergolong sebagai ekspektoran yang membantu mengeluarkan lendir (dahak) dari saluran napas. Penggunaan guaiafenesin dapat membantuk pasien melegakan batuk yang disertai dahak serta chest congestion yang disebabkan karena flu. Guaiafenesin juga dapat digunakan sebagai lini kedua dalam penanganan bronkitis kronis (Albrecht, et al., 2017).

Potassium iodide atau kalium iodide $(\mathrm{KI})$

Merupakan mukolitik atau pengencer dahak (Garbis, 2007).

Ammonium klorida

Merupakan ekspektoran yang bekerja terhadap mukosa bronki sehingga produksi cairan saluran pernapasan yang berlebihan dapat dikeluarkan dengan lebih mudah (https://www.drugbank.ca/drugs/DB06767).

\section{Batuk Kering}

Dektromethorphan $\mathrm{HBr}$

Obat ini merupakan antitusif yang berfungsi untuk menekan batuk yang cukup kuat dengan meningkatkan ambang batuk dengan melawan reseptor $\mathrm{N}$-metil-D-aspartat (NMDA) di sistem saraf pusat (Ramsay, et al., 2008).

\section{Batuk Alergi}

\section{Difenhidramin $\mathrm{HCl}$}

Obat ini merupakan antialergi sehingga dapat mengurangi batuk yang mungkin disebabkan karena adanya reaksi alergi dengan memblok reseptor H1. Selain memblok reseptor alergi, difenhidramin juga dapat menekan refleks batuk pada pusat batuk. Difenhidramin dapat menyebabkan kantuk.

Fexofenadine (antialergi generasi kedua)

Fexofenadine memiliki efek sedasi yang sangat rendah atau hampir tidak ada karena tidak dapat memasuki sawar otak seperti difenhidramin. Adapula antialergi (antihistamin) generasi kedua lainnya adalah loratadine.

\section{Kesimpulan}

Setelah mengetahui kegunaan-kegunaan zat-zat tersebut, alangkah baiknya jika pasien menjadi lebih bijak dan cerdas dalam memilih obat yang tepat dan sesuai dengan keluhan yang dirasakan. Konsultasikanlah kepada apoteker dalam untuk memastika pilihan obatnya. 


\section{Daftar Pustaka}

Albrecht, H. H., Dicpinigaitis, P. V., and Guenin, E. P. 2017. Role of guaiafenesin in the management of chronic bronchitis and upper respiratory tract infections. Multidisciplinary respiratory Medicine. 12(31):

Garbis, H. 2007. Drug During Pregnancy and Lactation (Second Edition). United States: Academic Press

https://www.drugbank.ca/drugs/DB06767.

lyer RK, Joshi JM. Future drugs for the treatment of dry cough. J Assoc Physicians India. 2013;61(Suppl 5):14-6

Rai, S. P. 2013. Chronic Cough. Suppl to journal of the association of physicians of India. 61: 28-30.

Ramsay, J., Wright, C., Thompson, R., Hull, D., and Morice A. H. 2008 Assessment of antitussive efficacy of dextromethorphan in smoking related cough: objective vs. subjective measures. Br J Clin Pharmacol. 65:737-741

Simpson, C. B. dan Amin, M. R. 2006. Chronic cough: state-of-the-art review. Otolaryngol Head Neck Surg. 134(4):693-700.

Singh S, Singh V. Combating cough-etiopathogenesis. J Assoc Physicians India. 2013;61(Suppl 5):6-7. 